\title{
Front Matter: Volume 9820
}

, "Front Matter: Volume 9820," Proc. SPIE 9820, Infrared Imaging Systems: Design, Analysis, Modeling, and Testing XXVII, 982001 (2 July 2016); doi: 10.1117/12.2244359

SPIE. Event: SPIE Defense + Security, 2016, Baltimore, MD, United States 


\section{PROCEEDINGS OF SPIE}

\section{Infrared Imaging Systems: \\ Design, Analysis, Modeling, and Testing XXVII}

Gerald C. Holst

Keith A. Krapels

Editors

19-21 April 2016

Baltimore, Maryland, United States

Sponsored and Published by

SPIE 
The papers in this volume were part of the technical conference cited on the cover and title page. Papers were selected and subject to review by the editors and conference program committee. Some conference presentations may not be available for publication. Additional papers and presentation recordings may be available online in the SPIE Digital Library at SPIEDigitallibrary.org.

The papers reflect the work and thoughts of the authors and are published herein as submitted. The publisher is not responsible for the validity of the information or for any outcomes resulting from reliance thereon.

Please use the following format to cite material from this book:

Author(s), "Title of Paper," in Infrared Imaging Systems: Design, Analysis, Modeling, and Testing XXVII, edited by Gerald C. Holst, Keith A. Krapels, Proceedings of SPIE Vol. 9820 (SPIE, Bellingham, WA, 2016) Six-digit Article CID Number.

ISSN: 0277-786X

ISSN: 1996-756X (electronic)

ISBN: 9781510600614

Published by

SPIE

P.O. Box 10, Bellingham, Washington 98227-0010 USA

Telephone +1 3606763290 (Pacific Time) · Fax +1 3606471445

SPIE.org

Copyright (C) 2016, Society of Photo-Optical Instrumentation Engineers.

Copying of material in this book for internal or personal use, or for the internal or personal use of specific clients, beyond the fair use provisions granted by the U.S. Copyright Law is authorized by SPIE subject to payment of copying fees. The Transactional Reporting Service base fee for this volume is $\$ 18.00$ per article (or portion thereof), which should be paid directly to the Copyright Clearance Center (CCC), 222 Rosewood Drive, Danvers, MA 01923. Payment may also be made electronically through CCC Online at copyright.com. Other copying for republication, resale, advertising or promotion, or any form of systematic or multiple reproduction of any material in this book is prohibited except with permission in writing from the publisher. The CCC fee code is 0277-786X/16/\$18.00.

Printed in the United States of America.

Publication of record for individual papers is online in the SPIE Digital Library.

\section{SPIE. DIGITAL}

Paper Numbering: Proceedings of SPIE follow an e-First publication model, with papers published first online and then in print. Papers are published as they are submitted and meet publication criteria. A unique citation identifier (CID) number is assigned to each article at the time of the first publication. Utilization of CIDs allows articles to be fully citable as soon as they are published online, and connects the same identifier to all online, print, and electronic versions of the publication. SPIE uses a six-digit CID article numbering system in which:

- The first four digits correspond to the SPIE volume number.

- The last two digits indicate publication order within the volume using a Base 36 numbering

system employing both numerals and letters. These two-number sets start with 00, 01, 02, 03, 04, $05,06,07,08,09,0 \mathrm{~A}, 0 \mathrm{~B} \ldots \mathrm{.0Z}$, followed by 10-1Z, 20-2Z, etc.

The CID Number appears on each page of the manuscript. The complete citation is used on the first page, and an abbreviated version on subsequent pages. the six-digit CID number. 


\title{
Contents
}

\author{
vii Authors \\ ix Conference Committee
}

SESSION 1 MODELING I

982002 Investigating binocular summation in human vision using complementary fused external noise [9820-1]

982003 Method and tool for generating and managing image quality allocations through the design and development process [9820-2]

982004 Modeling threshold detection and search for point and extended sources [9820-3]

982006 Reflective band image generation in the night vision integrated performance model [9820-5]

\section{SESSION 2 MODELING II}

982007 Measured system component development for the night vision integrated performance model (NV-IPM) [9820-6]

982008 Comparison of relative effectiveness of video with serial visual presentation for target reconnaissance from UASs [9820-7]

982009 Modeling demosaicing of color corrected cameras in the NV-IPM [9820-51]

9820 OA Comparing and contrasting 2D versus 1D performance modeling in NV-IPM v1.6 [9820-9]

SESSION 3 MODELING III

$9820 \mathrm{OB} \quad$ Model development and system performance optimization for staring infrared search and track (IRST) sensors [9820-10]

$98200 \mathrm{C}$ Is there an optimum detector size for digital night vision goggles? [9820-1 1]

9820 OD Efficient polarimetric BRDF transformations [9820-52]

$9820 \mathrm{OE}$ A wavelet contrast metric for the targeting task performance metric [9820-13] 
SESSION 4 MODELING IV

9820 OF Performance assessment of a single-pixel compressive sensing imaging system [9820-14]

$98200 \mathrm{G} \quad$ Unified characterization of imaging sensors from VIS through LWIR [9820-15]

SESSION 5 MODELING V

9820 Ol NIR sensitivity analysis with the VANE [9820-17]

9820 0J Foote's Law and its application to cameras [9820-18]

9820 OK Spatially resolved 3D noise [9820-19]

\section{SESSION 6 MODELING VI}

9820 OM Hyperhemispheric multifunction sensors for ground combat vehicles: concept evaluation using virtual prototyping (Invited Paper) [9820-21]

9820 ON HIL range performance of notional hyperspectral imaging sensors [9820-23]

982000 Scenario-based analysis of binning in MWIR detectors for missile applications [9820-25]

SESSION 7 MODELING VII

$98200 Q \quad$ An imaging system detectivity metric using energy and power spectral densities [9820-27]

9820 OR The analysis and rationale behind the upgrading of existing standard definition thermal imagers to high definition [9820-28]

9820 OS Characterization and recognition of mixed emotional expressions in thermal face image [9820-29]

\section{SESSION 8 TEST I}

9820 OU Thermal system field performance predictions from laboratory and field measurements (Invited Paper) [9820-31]

9820 OV Novel approach to characterize and compare the performance of night vision systems in representative illumination conditions [9820-32]

9820 OW Noise measurement on thermal systems with narrow band [9820-33] 
9820 0X Development of a high-definition IR LED scene projector [9820-35]

9820 OY Display MTF measurements based on scanning and imaging technologies and its importance in the application space [9820-36]

$98200 Z$ Achieving ultra-high temperatures with a resistive emitter array [9820-37]

982010 Automated and semi-automated field testing of night vision goggles [9820-38]

SESSION $10 \quad$ TEST III

982013 Real-time simulation of thermal shadows with EMIT [9820-41]

SESSION 11 TARGETS, BACKGROUNDS, ATMOSPHERICS, AND SIMULATION I

982014 Simulation of whitecaps and their radiometric properties in the SWIR [9820-42]

982015 Investigation of the dynamic thermal infrared signatures of a calibration target instrumented with a network of 1-wire temperature sensors [9820-43]

982016 Image based performance analysis of thermal imagers [9820-44]

SESSION 12 TARGETS, BACKGROUNDS, ATMOSPHERICS, AND SIMULATION II

982017 Application of cooled IR focal plane arrays in thermographic cameras [9820-45]

982018 3D flare particle model for ShipIR/NTCS [9820-46]

982019 Digital imaging and remote sensing image generator (DIRSIG) as applied to NVESD sensor performance modeling [9820-47]

$98201 \mathrm{~A} \quad$ Multi-spectral synthetic image generation for ground vehicle identification training [9820-48]

9820 1B New technologies for HWIL testing of WFOV, large-format FPA sensor systems [9820-50] 
Proc. of SPIE Vol. $9820982001-6$

Downloaded From: https://www.spiedigitallibrary.org/conference-proceedings-of-spie on 26 Apr 2023 Terms of Use: https://www.spiedigitallibrary.org/terms-of-use 
Proc. of SPIE Vol. $9820982001-8$

Downloaded From: https://www.spiedigitallibrary.org/conference-proceedings-of-spie on 26 Apr 2023 Terms of Use: https://www.spiedigitallibrary.org/terms-of-use 


\title{
Conference Committee
}

\author{
Symposium Chair
}

David A. Logan, BAE Systems (United States)

Symposium Co-chair

Donald A. Reago Jr., U.S. Army Night Vision \& Electronic Sensors

Directorate (United States)

Conference Chairs

Gerald C. Holst, JCD Publishing (United States)

Keith A. Krapels, U.S. Army Night Vision \& Electronic Sensors

Directorate (United States)

Conference Program Committee

Gisele Bennett, Georgia Institute of Technology (United States)

Piet Bijl, TNO Defence, Security and Safety (Netherlands)

James A. Dawson, Dynetics, Inc. (United States)

Ronald G. Driggers, St. Johns Optical Systems (United States)

Richard L. Espinola, U.S. Army Night Vision \& Electronic Sensors

Directorate (United States)

David P. Forrai, L-3 Communications Cincinnati Electronics

(United States)

David P. Haefner, U.S. Army Night Vision \& Electronic Sensors

Directorate (United States)

Jonathan G. Hixson, U.S. Army Night Vision \& Electronic Sensors

Directorate (United States)

Alan Irwin, Santa Barbara Infrared, Inc. (United States)

Eddie L. Jacobs, University of Memphis (United States)

Terrence S. Lomheim, The Aerospace Corporation (United States)

Teresa L. Pace, L-3 Communications (United States)

Endre Repasi, Fraunhofer-Institut für Optronik, Systemtechnik und

Bildauswertung (Germany)

Hector M. Reyes, Raytheon Company (United States)

Joseph P. Reynolds, U.S. Army Night Vision \& Electronic Sensors

Directorate (United States)

Bernard M. Rosier, ONERA (France)

Michael A. Soel, FLIR Systems, Inc. (United States)

Andrew W. Sparks, L-3 Sonoma EO (United States)

Curtis M. Webb, Northrop Grumman Electronic Systems

(United States) 
Session Chairs

1 Modeling I

Andrew W. Sparks, L-3 Sonoma EO (United States)

2 Modeling II

Andrew W. Sparks, L-3 Sonoma EO (United States)

3 Modeling III

Jonathan G. Hixson, U.S. Army Night Vision \& Electronic Sensors Directorate (United States)

4 Modeling IV

Keith A. Krapels, U.S. Army Night Vision \& Electronic Sensors Directorate (United States)

5 Modeling $\vee$

James A. Dawson, Dynetics, Inc. (United States)

$6 \quad$ Modeling $\mathrm{VI}$

Hector M. Reyes, Raytheon Company (United States)

$7 \quad$ Modeling VII

Joseph P. Reynolds, U.S. Army Night Vision \& Electronic Sensors

Directorate (United States)

8 Test I

Alan Irwin, Santa Barbara Infrared, Inc. (United States)

Curtis M. Webb, Northrop Grumman Electronic Systems (United States)

David P. Haefner, U.S. Army Night Vision \& Electronic Sensors Directorate (United States)

9 Test II

Alan Irwin, Santa Barbara Infrared, Inc. (United States)

Curtis M. Webb, Northrop Grumman Electronic Systems (United States)

David P. Haefner, U.S. Army Night Vision \& Electronic Sensors Directorate (United States)

10 Test III

Alan Irwin, Santa Barbara Infrared, Inc. (United States)

Curtis M. Webb, Northrop Grumman Electronic Systems (United States)

David P. Haefner, U.S. Army Night Vision \& Electronic Sensors

Directorate (United States) 
11 Targets, Backgrounds, Atmospherics, and Simulation I

Richard L. Espinola, U.S. Army Night Vision \& Electronic Sensors

Directorate (United States)

Endre Repasi, Fraunhofer-Institut für Optronik, Systemtechnik und Bildauswertung (Germany)

12 Targets, Backgrounds, Atmospherics, and Simulation II

Richard L. Espinola, U.S. Army Night Vision \& Electronic Sensors Directorate (United States)

Endre Repasi, Fraunhofer-Institut für Optronik, Systemtechnik und Bildauswertung (Germany)

Bernard M. Rosier, ONERA (France) 
Proc. of SPIE Vol. $9820982001-12$

Downloaded From: https://www.spiedigitallibrary.org/conference-proceedings-of-spie on 26 Apr 2023 Terms of Use: https://www.spiedigitallibrary.org/terms-of-use 